\title{
Article
}

\section{The Influence of Seed Production Environment on Seed Development and Quality of Soybean (Glycine max (L.) Merrill)}

\author{
Indika Weerasekara ${ }^{1,2} \mathbb{D}_{\text {, Uma Rani Sinniah }}{ }^{1, *}$, Parameswari Namasivayam ${ }^{3}$, Muhamad Hazim Nazli ${ }^{1}$, \\ Sharif Azmi Abdurahman ${ }^{1}$ (D) and Mohd Norsazwan Ghazali ${ }^{1}$ (D)
}

1 Department of Crop Science, Faculty of Agriculture, Universiti Putra Malaysia, Selangor 43400, Malaysia; weerasekaradoa@gmail.com (I.W.); m_hazim@upm.edu.my (M.H.N.); sh.azmi@ums.edu.my (S.A.A.); mohdnorsazwan@gmail.com (M.N.G.)

2 Seed and Planting Material Development Center, Department of Agriculture, Peradeniya, Kandy 20400, Sri Lanka

3 Department of Cell and Molecular Biology, Faculty of Biotechnology and Biomolecular Sciences, Universiti Putra Malaysia, Selangor 43400, Malaysia; parameswari@upm.edu.my

* Correspondence: umarani@upm.edu.my; Tel.: +60-172-551-500 or +60-397-694-839

Citation: Weerasekara, I.; Sinniah, U.R.; Namasivayam, P.; Nazli, M.H.; Abdurahman, S.A.; Ghazali, M.N. The Influence of Seed Production Environment on Seed Development and Quality of Soybean (Glycine max (L.) Merrill). Agronomy 2021, 11, 1430 https://doi.org/10.3390/ agronomy 11071430

Academic Editor: Jose Maria Barrero

Received: 13 June 2021

Accepted: 14 July 2021

Published: 17 July 2021

Publisher's Note: MDPI stays neutral with regard to jurisdictional claims in published maps and institutional affiliations.

Copyright: (c) 2021 by the authors. Licensee MDPI, Basel, Switzerland. This article is an open access article distributed under the terms and conditions of the Creative Commons Attribution (CC BY) license (https:// creativecommons.org/licenses/by/ $4.0 /)$.

\begin{abstract}
The aim of the study was to determine the effect of seed production environment in Sri Lanka on seed development, maturation, and subsequent seed quality. The experiment was conducted at six production environments, three locations (Mahailluppalama (M1), Polonnaruwa (POL), and Aluttarama (ALU), over two planting cycles (P1, P2). Seed development and maturation, seed and seedling quality characteristics were evaluated at five reproductive (R6, R7, R8, R8 + 5 and $R 8+10)$ maturity stages. The study infers that production environment at the late reproductive (LR) stage (R6-R8) was critical in determining the seed quality. If the LR stage coincided with cumulative rainfall (RF) over $100 \mathrm{~mm}$ or above $75 \%$ relative humidity $(\mathrm{RH})$, categorized as wet environment, around 27.5 days was required for the completion of seed maturation compared with only 17.5 days in dry environment. Seed lots from dry environment during LR stage surpassed the minimum quality standards (75\% final germination, germination index of 300 , germination rate index of $25 \%$ per day, seedling vigor index of 2500 and $15 \mu \mathrm{mol} / \mathrm{min} / \mathrm{mg}$ FW catalase activity) at maturity stage R7 onwards, while this only occurred at maturity stage R8 for wet environment. A significant negative correlation $\left(\mathrm{r}=-0.50^{* *}\right)$ was observed between glucose content, antioxidant enzyme activities and germination percentage. In conclusion, the findings provide useful information for the expansion of areas for seed production in Sri Lanka.
\end{abstract}

Keywords: soybean; harvest maturity stages; seed quality; habitat; soluble sugar; antioxidant enzyme

\section{Introduction}

Soybean (Glycine max (L.) Merrill) is a legume that is grown in tropical, subtropical, and temperate climates, which belongs to the family Fabaceae or Leguminosae, subfamily Faboideae [1]. The crop has gained significant importance in the national food production program in Sri Lanka because of the high demand as a feed in the livestock industry. According to Sri Lanka's National Food Production Program's (NFPP) indicative targets, it is required to increase cultivation from 7000 ha up to 42,175 ha to reduce the soybean importation up to $70 \%$ [2]. One of the major constraints in achieving the above is insufficient supply of quality seeds for crop production. Currently, PB-1 is the sole variety used in Sri Lanka, and seed production is carried out only in the north-central part of the country [3]. Therefore, new areas suitable for seed production need to be identified by ensuring the environment is suitable to produce quality seeds.

Seed development upon fertilization undergoes a series of processes such as morphogenesis, reserve accumulation culminating in physiological maturity (PM), followed by maturation drying [4]. The seed development process is determined by both the 
genetics and the environmental factors including soil fertility, water, temperature, day length, relative humidity, and rainfall [5-8]. Water deficit condition during plant growth and development leads to reduced plant metabolism and seed development due to reduced photosynthetic rate, assimilate production and translocation to the developing seeds $[7,9,10]$. It was reported that an increase in temperature $\left(>35^{\circ} \mathrm{C}\right)$ may decrease seed mass because of the higher growth rate and reduced seed filling duration, while low temperatures $\left(<15-17^{\circ} \mathrm{C}\right)$ retard seed growth $[5,7,11]$. When water is fully available throughout the vegetative periods of soybean due to sufficient rainfall, proper vegetative period is ensured, and flowering period was extended [12], leading to enhanced duration for assimilates during the seed development. Lack of light availability to the parent plants or short-day conditions also influenced development by negatively affecting seed size and weight, decreased photosynthesis, and resulting in smaller seeds [13]. The abovementioned environmental conditions during the process of seed development may lead to changes in chemical composition of the seed and influence the final seed quality [14-16]. The term "Seed quality" is used in agriculture to describe the overall value of a seed lot which encompasses germinability, vigor, genetic and physical purity, and seed health $[5,6]$. Pádua et al. [14] reported that environmental conditions, and field weather (temperature, rainfall and relative humidity) influence the quality of seeds throughout the growing periods. According to Alsajri et al. [17], the interaction between soybean cultivar and temperature influences soluble sugar (glucose, sucrose and raffinose family oligosaccharides (RFOs)) content of the seeds, but the sucrose and raffinose content declined when temperature increased. Soluble sugars are a vital seed constituent, for example, sucrose promotes seed filling, whereas RFOs may increase seed vigor under stressful environments [18]. However, the role of soluble sugars under variable production environment is still not understood completely. Harvesting seeds at the appropriate stage is also an important factor that determines seed quality. Tsukahara et al. [19] reported that rainfall during the late stage of seed development affected final seed quality. While the combined effect of high moisture content in seeds and hot temperatures intensified the respiration processes, thus consuming seed reserves and, consequently, reducing their quality, which is vital for development of the seedling [20]. Unfavorable ambient factors could trigger the formation of reactive oxygen species (ROS) which tend to build up and cause degradation of seed plasma membranes, therefore, reducing their vigor. On the other hand, plants have complex defense mechanisms to regulate the damage to cellular membranes and organelles by scavenging ROS based on two approaches: enzymatic (catalase, peroxidase, superoxide dismutase and others) and non-enzymatic pathways (ascorbate, glutathione, alpha-tocopherols and others) [21,22].

The above examples clearly imply that the production environment directly affects seed maturation process and the time taken to harvest the crop which determine the final seed quality. Furthermore, grain moisture loss during seed maturation depends on both the air temperature and relative humidity, and the seed moisture at harvest affected seed quality directly [23]. According to Diniz et al. [24] it is not always possible to harvest the seeds at the right time due to various factors, and it leads to loss in both the physiological and sanitary qualities of seeds. Therefore, harvesting soybean seeds at proper maturity stage is very important to maintain maximum seed vigor, seed viability as well as to reduce the seeds loss. According to Fehr and Caviness [25] reproductive stages (R) of soybean are divided into eight stages, and out of them $\mathrm{R} 5$ is being associated with the beginning of seed development, R6 is associated with the full seed stage, R7 denotes beginning of the mature stage, and R8 is considered as full mature stage. These stages have become the basis for harvesting soybean. Interestingly, based on previous studies three maturity stages have been proposed for harvesting soybean to ensure maximum seed quality, which are R7 stage [26-29], R8 stage [28,30], and a few days (3-21 days) after R7 stage [31]. Currently, the variety PB-1 is harvested 90 days after sowing without taking into consideration the environmental conditions and seed maturity stages. As a result, vast variations can be seen in germinability (30-90\%) and storability (1-8 months). 
Most of the studies discussed above were conducted in controlled environment conditions, thus the knowledge on the effect of multiple field environmental condition on physiological, biochemical quality traits, and yield of soybean is limited. Therefore, it is important to investigate seed maturity and quality changes under different production environments in the field. This would be helpful for the decision support system for harvesting soybean while preserving maximum seed quality under different environmental conditions. Moreover, it will help to expand the seed production program in Sri Lanka.

\section{Materials and Methods}

\subsection{Study Location}

Soybean seeds were sown at three seed production farms at Aluttarama (ALU, $\left.7.24^{\circ} \mathrm{N} 81.00^{\circ} \mathrm{E}\right)$, Polonnaruwa (POL, $\left.7.94^{\circ} \mathrm{N} 81.02^{\circ} \mathrm{E}\right)$, and Mahailluppallama $\left(\mathrm{MI} 8.11^{\circ} \mathrm{N}\right.$ $\left.81.00^{\circ} \mathrm{E}\right)$, in Sri Lanka at two consecutive planting cycles. Planting one (P1) was conducted from December 2018 to April 2019 and planting two (P2) was conducted from June 2019 to October 2019. Three locations were selected mainly due to variations in rainfall intensities, and the long term (2009-2019) mean annual rainfall recorded in MI, POL, and ALU were 1500,1900 , and $2100 \mathrm{~mm}$, respectively. In all three locations, the field is one that is used for maize soybean crop rotation. The soil type for all three locations was Low Humic Gley soil (HGL), with moderate acidic pH (5.1-5.9), low EC (0.027-0.055 dS/m), low available phosphorus (5.4-16.7 ppm) and low exchangeable potassium (55.5-90.9 ppm) content based on soil test.

\subsection{Crop Establishment}

The experimental area was prepared by measuring a plot of $7.2 \times 8.5 \mathrm{~m}$, divided equally into 15 plots $(2.4 \times 1.7 \mathrm{~m})$, in each location. The plots were assigned accordingly into 5 treatments (maturity stages) with 3 replications in a randomized manner. Seeds of soybean variety PB-1 were planted at a spacing of $60 \mathrm{~cm}$ between rows, and $10 \mathrm{~cm}$ between plants, maintaining 16.7 plants per square meter. Urea (50 kg ha $\left.{ }^{-1}\right)$, muriate of potash (75 kg ha $\left.{ }^{-1}\right)$, and triple superphosphate $\left(150 \mathrm{~kg} \mathrm{ha}^{-1}\right)$ were added as basal fertilizer at the time of land preparation [32]. At the onset of flowering, $100 \mathrm{~kg} \mathrm{ha}^{-1}$ of urea was applied as top-dressing. Irrigation was done daily up to 65 days from sowing, and alternate days thereafter using a sprinkler system. Manual weed control was done using a hand hoe.

\subsection{Treatment and Experimental Design}

The experiment was arranged in a randomized complete block design (RCBD) in three replicates. Plants were observed daily from seed sowing (SS) until full seed stage (R6), beginning of mature stage (R7), and full mature stage (R8). The treatments for this study consisted of five different maturity stages (full seed stage-R6, beginning of mature-R7, full mature stage $-\mathrm{R} 8$, and two late mature stages $\mathrm{R} 8+5$ days, and $\mathrm{R} 8+10$ days) for each production environment, and the same design was used in all six production environments (ALU-P1, ALU-P2, POL-P1, POL-P2, MI-P1, and MI-P2).

\subsection{Handling at Harvest}

Six plants were selected randomly and tagged from the middle row (out of 5 rows) of each plot to record the time when pods attained a particular growing stage based on the method described by Fehr and Caviness, [25]. The reproductive stages were recorded when $50 \%$ of the selected plants of each plot reached the particular maturity stage [33]. Harvesting was done at five different times based on the maturity stages (R6, R7, R8, R8 +5 days R8 +10 days) and at each harvest, the middle 45 plants per replications $(45 \times 3)$ excluding the borders, were removed separately. The harvested crop was then sun-dried for three days and thereafter, the dried pods were carefully hand threshed and cleaned before it was sun-dried until the moisture content was less than $9.0 \%$. 


\subsection{Data Collection and Measurements}

\subsubsection{Weather}

The daily meteorological data (rainfall, temperature, and relative humidity) were obtained for each location from the weather station maintained by each seed production farm. The growing degree days were calculated for all production environments based on the method described by Kumar et al. [34]. The weather data from 2009 to 2019 were obtained from the Natural Resources Management Division of Department of Agriculture Sri Lanka to forecast the long-term environment variations of each location.

\subsubsection{Seed Moisture}

Seed moisture content (fresh weight basis) was determined using three replicates of 25 seeds from each treatment and subjected to oven drying using the low constant temperature method $\left(105^{\circ} \mathrm{C}\right.$ for $\left.24 \mathrm{~h}\right)$ which was introduced by Khan et al. [26].

\subsubsection{Yield per Square Meter}

Seed yield was estimated per square meter by adjusting the moisture content to $10 \%$ and expressed in grams per square meter $\left(\mathrm{gm}^{-2}\right)$.

\subsubsection{Germination and Vigor}

Germination test was conducted with four replications for each experimental unit at room temperature $\left(28 \pm 2{ }^{\circ} \mathrm{C}\right)$ using sterilized sand as described by ISTA [35]. Seed germination was counted daily for seven consecutive days. On the seventh day, the number of normal seedlings was counted, and expressed as germination percentage. According to Kader and Jutzi [36], the daily germination count data was used to calculate the germination index (GI). The germination rate index (GRI), mean germination time (MGT), and the coefficient velocity of germination (CVG) were estimated using the method introduced by Al-Ansari and Ksiksi [37]. Seedling vigor index (SVI) was calculated as described by Abdul-Baki and Anderson, [38].

\subsubsection{Electrical Conductivity of Leachates}

Twenty-five seeds were weighed and soaked in a container containing $75 \mathrm{~mL}$ deionized water for $24 \mathrm{~h}$ at $20^{\circ} \mathrm{C}$ [39]. Electrical conductivity of leachate was measured using a digitalized conductivity meter (labCHEM-CP conductivity meter) and expressed as $\mu \mathrm{S} \mathrm{cm}^{-1} \mathrm{~g}^{-1}$.

\subsubsection{Soluble Sugars}

The Raffinose/Sucrose/D-Glucose assay kit (Megazyme) was used to detect the soluble carbohydrate concentration of soybean seeds. Two grams of seeds were ground using a mortar and pestle and homogenized with $5 \mathrm{~mL}$ of ethanol $(95 \% \mathrm{v} / \mathrm{v})$ before incubation in a water bath at $84-88^{\circ} \mathrm{C}$ for $5 \mathrm{~min}$ to inactivate endogenous enzymes. The final volume was adjusted up to $50 \mathrm{~mL}$ using sodium acetate buffer $(50 \mathrm{mM}, \mathrm{pH} 4.5)$ and incubated at room temperature for $15 \mathrm{~min}$ and vortexed to obtain a uniform slurry. In total, $5 \mathrm{~mL}$ of the slurry was taken, and $2 \mathrm{~mL}$ chloroform was added and centrifuged at $1000 \times g$ for $10 \mathrm{~min}$. The supernatant was used to analyze soluble sugar, in which $0.2 \mathrm{~mL}$ of the supernatant was added with $0.2 \mathrm{~mL}$ sodium acetate buffer to glucose. For sucrose, $0.2 \mathrm{~mL}$ of the supernatant was added with $0.2 \mathrm{~mL}$ of invertase $(8.3 \mathrm{U} / \mathrm{mL})$ while for raffinose, a mixture of invertase $+\alpha$-GAL (invertase $8 \mathrm{U} / \mathrm{mL}$ and $\alpha$-GAL $40 \mathrm{U} / \mathrm{mL}$ ) was added. All mixtures were incubated at $50{ }^{\circ} \mathrm{C}$ for $20 \mathrm{~min}$. Afterwards, $3 \mathrm{~mL}$ of GOPOD reagent provided by the manufacturer (Megazyme) was added in all tubes and incubated again at $50{ }^{\circ} \mathrm{C}$ for $20 \mathrm{~min}$. Absorbance was read at $510 \mathrm{~nm}$ using micro-plate spectrophotometer (Thermo scientific MULTISKAN GO). Soluble sugars were calculated according to Raman et al. [40], and concentrations were presented in $\mathrm{mmol} / 100 \mathrm{~g}$ seed fresh weight. 


\subsubsection{Antioxidant Enzymes}

A spectrophotometer (Shimadzu UV-3150 UV-VIS Near IR) was used to detect defensive mechanisms (catalase (CAT) and peroxidase (POD) activities). Ground soybean powder $(0.15 \mathrm{~g})$ was homogenized with $1.5 \mathrm{~mL}$ of $100 \mathrm{mM}$ potassium phosphate buffer (pH 7) using cold mortar and pestle. Each extracted sample was centrifuged at 13,500 rpm for $20 \mathrm{~min}$ at $4{ }^{\circ} \mathrm{C}$. The supernatant was used to determine the CAT and POD activities. Three replications were tested for each treatment combination. Catalase (CAT) activity was calculated according to the method described by Aebi [41], and activity unit was presented as per milligram of extractable fresh weight $(\mu \mathrm{mol} / \mathrm{min} / \mathrm{mg} / \mathrm{FW})$. While, Guaiacol peroxidase (POD) activity was measured as described by Maehly [42]. POD enzyme activity was expressed per milligram of extractable fresh tissue.

\subsection{Data Analysis}

GLM procedure was used to analyze the data for each environment (location $\times$ planting cycle) individually with randomized complete block design (RCBD), Bartlett's test $(p \leq 0.05)$ was used to verify the homogeneity of the data. If the variance is homogeneous, data is subjected to the combined analysis of variance (ANOVA) with the PROC GLM procedure in SAS using the RANDOM statement set to the test option. Environments were considered as random effects, while maturity stages were treated as fixed effects. Each environment was defined as location $\times$ planting time, and the LS-means were separated at $p<0.05$. Pearson correlation analysis was performed among studied parameters by CORR procedure using SAS version 9.4 (SAS Institute Inc., 2012).

\section{Results}

\subsection{Seed Development, Maturation in Different Production Environments}

The total growing period (TGP) of soybean was influenced by the production environment. Time taken from seed sowing (SS) to R8 fluctuated from 80.8 to 100.4 days, being significantly different across the production environments $(p<0.05)$.

To understand the influence of production environment, the total growing period (TGP) was partitioned into three stages; (i) seed sowing (SS) to flowering (R1) as vegetative (VEG), (ii) flowering to full seed stage (R6) as early reproductive (ER), and (iii) full seed stage to full mature stage (R8) as late reproductive stage (LR). Number of days taken by plants under each production environment to complete the different developmental stages is presented in Figure 1, and the influence of weather conditions on the development and maturation is explained below.

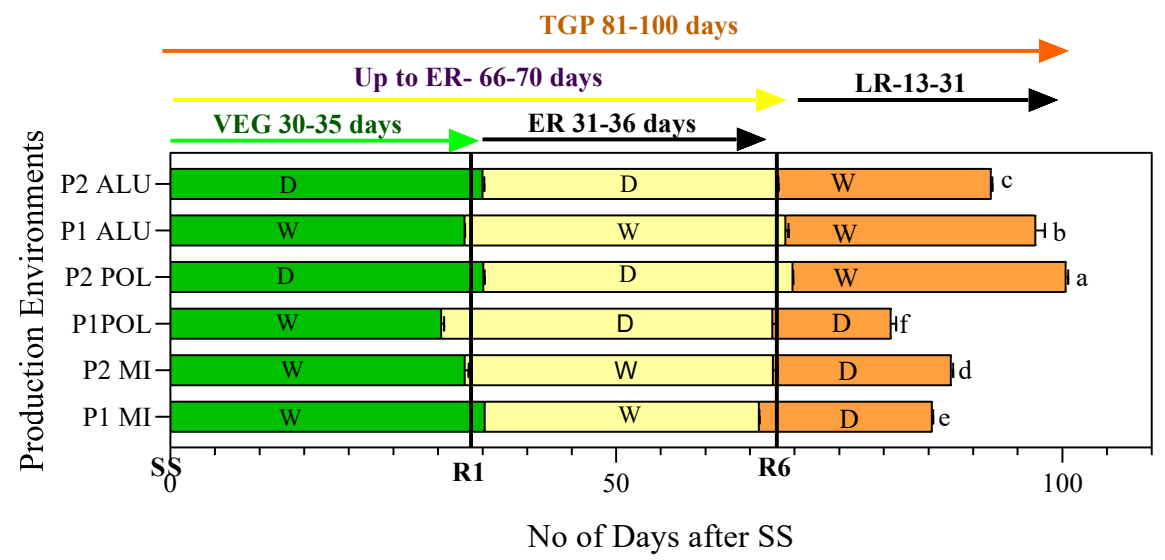

Figure 1. Number of days taken to complete different growing stages in soybean grown at different production environments. Growth phases were recorded according to Fehr and Caviness [25], whereby R1 indicates beginning of flowering, R6, full seed, and R8, fully matured seeds. Total growing period (TGP) means followed by the same letter (s) in the column do not differ significantly, LSD at $p<0.05$. Note: VEG—vegetative; ER-early reproductive; LR-late reproductive. 
Different weather conditions were observed in each location during the cropping period, as in planting 1 (P1) (December 2018 to April 2019) and Planting 2 (P2) (June 2019September 2019). The summary of meteorological data (maximum temperature, growing degree days (GDD), average relative humidity and cumulative rainfall) during vegetative, early reproductive, and late reproductive periods for the six production environments are presented in Table 1.

Table 1. Maximum temperature $\left({ }^{\circ} \mathrm{C}\right)$, growing degree days (GDD), average relative humidity $(\mathrm{RH} \%)$ and cumulative rainfall $(\mathrm{mm})$ during vegetative (SS-R1), early reproductive (R1-R6) and late reproductive (R6-R8) at six production environments.

\begin{tabular}{|c|c|c|c|c|c|c|c|c|c|c|c|c|}
\hline \multirow{2}{*}{ PE } & \multicolumn{4}{|c|}{ Vegetative (SS-R1) } & \multicolumn{4}{|c|}{ Early Reproductive (R1-R6) } & \multicolumn{4}{|c|}{ Late Reproductive (R6-R8) } \\
\hline & $\operatorname{Max} \mathbf{T}^{\circ} \mathrm{C}$ & GDD & RH\% & $\mathrm{RF} \mathbf{m m}$ & $\operatorname{Max} \mathbf{T}^{\circ} \mathrm{C}$ & GDD & RH\% & RF mm & $\operatorname{Max} \mathbf{T}^{\circ} \mathrm{C}$ & GDD & RH\% & RF mm \\
\hline P1 MI & 29 & 526 & 78 & 172.4 & 31 & 473 & 76 & 42.8 & 34 & 388 & 68 & 0 \\
\hline P2 MI & 34 & 645 & 75 & 0.7 & 32 & 644 & 70 & 108.8 & 32 & 371 & 71 & 28.2 \\
\hline P1 POL & 31 & 502 & 78 & 109.6 & 35 & 708 & 61 & 0.7 & 36 & 260 & 68 & 78.6 \\
\hline P2 POL & 36 & 683 & 57 & 16.6 & 35 & 656 & 60 & 66 & 34 & 535 & 72 & 166.6 \\
\hline P1 ALU & 31 & 538 & 83 & 154.7 & 33 & 639 & 77 & 45.4 & 36 & 539 & 75 & 33.6 \\
\hline P2 ALU & 36 & 686 & 61 & 0 & 35 & 642 & 68 & 53.3 & 34 & 429 & 71 & 122.4 \\
\hline
\end{tabular}

Note: If relative humidity $>75 \%$ or/and rainfall $>100 \mathrm{~mm}$, the environment was considered as wet otherwise dry. Source: Meteorology unit Natural Resources Management Center-DOA-Sri Lanka. Values of wet environment are presented in bold.

According to the environmental data in Table 1, taking both $\mathrm{RH}$ and rainfall ( $\mathrm{RH}>75 \%$ or/and if rainfall $>100 \mathrm{~mm}$ ) into consideration during the different growing periods (VEG, ER, and LR), the production environments were classified as either wet (W) or dry (D) (Figure 1). The environmental conditions during the vegetative stage (SS-R1) at planting cycle 1 (P1-MI, P1-POL and P1-ALU) recorded comparatively low temperature $\left(29-31^{\circ} \mathrm{C}\right)$, low GDD (502-538), more than 75\% RH (78-83\%) and more than $100 \mathrm{~mm}$ of cumulative rainfall (109.6-172.4 mm). On the other hand, P2 (P2-MI, P2-POL and P2-ALU) experienced comparatively higher temperature $\left(34-36^{\circ} \mathrm{C}\right)$, high GDD (645-686), less than $75 \% \mathrm{RH}(57-75 \%)$ and extremely low values for cumulative rainfall $(0-16.6 \mathrm{~mm})$ during the vegetative growing periods. Despite the varied environmental conditions between the two planting cycles, the duration taken by the soybean plants to complete the vegetative growth were similar, ranging from 30 to 35 days (Figure 1). Hence the environmental condition had little influence on vegetative growth and development in terms of time taken to complete this phase.

During early reproductive stage, comparatively low temperature $\left(31-33^{\circ} \mathrm{C}\right)$ and high $\mathrm{RH}(70-77 \%)$ were recorded in the environments, for example, P1-MI, P2-M1, and P1-ALU, in contrast, production environments such as P1-POL, P2-POL, and P2-ALU experienced high temperature $\left(35^{\circ} \mathrm{C}\right)$ and low $\mathrm{RH}(60-68 \%)$. During this phase, the influence of environment was not reflected in the time taken to complete the phase (66-70 days). In the late reproductive stage production environments of P2-POL, P1-ALU, and P2-ALU exhibited more than 400 GDD (429-539), while less than 400 GDD (260-388) was shown in the remaining production environments; P1-MI, P2-M1, and P1-POL. During the early reproductive stage P1-M1, P2-M1, and P1-ALU experienced wet conditions while P1-POL, P2-POL, and P2-ALU experienced dry environments. In late reproductive stage P2-POL, P1-ALU, and P2-ALU experienced wet conditions, and dry conditions were experienced in P1-MI, P2-M1, and P1-POL (Figure 1 and Table 1).

The current study showed that the environment variation had lesser effect on the variation of the vegetative period and early reproductive periods of soybean grown in different production environments, and it ranged from 30 to 35 and 31 to 36 days, respectively. While the number of days taken from R6 to R8 fluctuated significantly among the environments (13-31 days) (Figure 1). Seeds that matured in wet condition (P1 ALU, P2 ALU, and P2 POL) had prolonged maturation period compared with the dry environments (P1 POL, P1, MI, and P2 MI). In the wet environment, 96.5 days were taken to reach the full maturity stage, and in the dry environment, only 84.5 days were taken. In other words, maturity was prolonged in the wet environment by 12 days. 
Seed and Seedling Quality

According to the analysis of variance, a significant difference was obtained among the production environment, maturity stages and its interaction on FG\%, GI, GRI, and SVI (Figure 2). Since environmental conditions affected the days to maturity during the LR stage, Figure 2 was constructed with the environment being categorized as wet and dry based on the definition given earlier, for the LR stage.
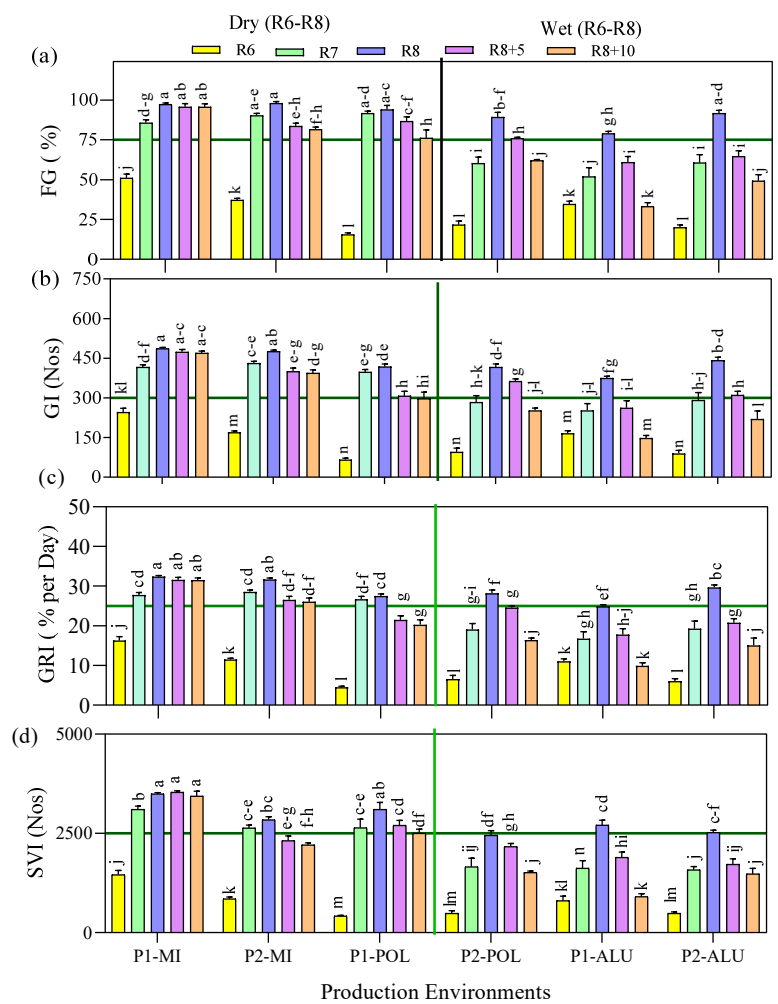

Figure 2. (a) Final germination percentage (FG\%), (b) germination index (GI), (c) germination rate index (GRI) and (d) seedling vigor index (SVI) as affected by the interaction between production environment (location $\times$ planting cycle) and maturity stages. Means followed by the same letters do not differ significantly between the production environments $\times$ maturity stages using Ls means at $p<0.05$. Wet and dry were grouped based on the late reproductive stage environmental condition.

Seed quality parameters (FG\%, GI, GRI and SVI) were higher in seeds harvested at R7 and R8 compared with R6. Another pertinent observation was that the seed quality decreased at the late maturity stages (R $8+5$ days and $R 8+10$ days) irrespective of the production environments except for P1-MI (Figure 2), where the germination percentage was maintained. The combined analysis showed that all the seeds produced under the wet condition (based on LR development), minimum quality standards (FG\% $>75 \%$, GI $>300$, GRI $>25 \%$ per day, and SVI $>2500$ ) were obtained at the maturity stage R8, while in dry environment, it was achieved at R7 (Figure 2), with significantly lower percentage in wet environments compared to dry.

The lowest seed quality traits $(\mathrm{FG} \%<51 \%$, GI $<250$, and GRI $<16.5)$ were recorded at R6, irrespective of the production environments. Thereafter, seed quality improved with maturity from R6 to R8. Upon reaching a maximum at R8, in most environments, quality began to decline at R8 +5 and R $8+10$, except for P1-MI where the seed quality was retained during the delayed maturity stages. Higher rate of the FG\% reduction was observed after the R8 maturity stage in P2-POL, P1-ALU, and P2-ALU (wet) by 31\%, 58\% and $46 \%$, respectively. In P2-MI and P1-POL (dry), comparatively slow rate of reduction was observed at same period by $6 \%$ and $19 \%$, respectively. A similar trend was observed for other seed and seedling quality parameters of GI, GRI and SVI. 
There was no interaction observed for MGT and CVG. However, significant differences for main factor were detected in MGT and CVG (Figure 3).

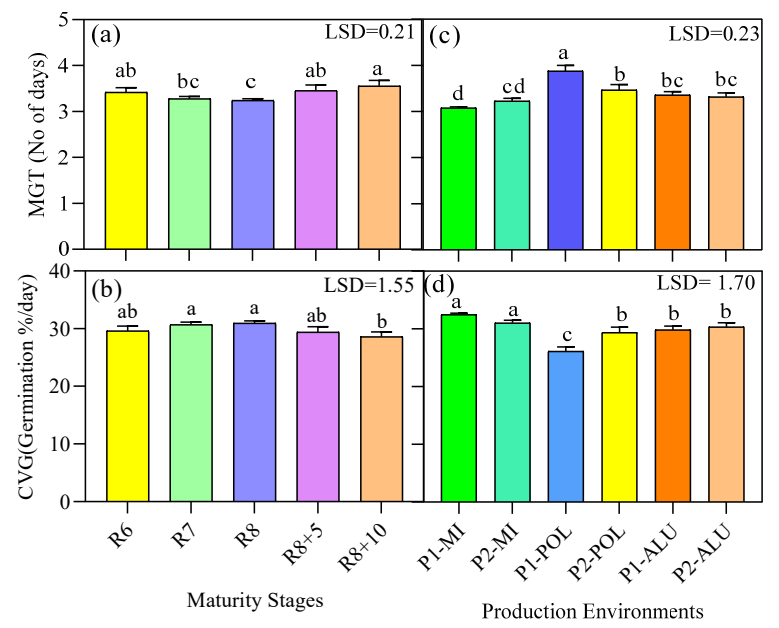

Figure 3. Mean germination time (MGT) and coefficient velocity of germination (CVG) as affected by different maturity stage $(\mathbf{a}, \mathbf{b})$ and different production environments (location $\times$ planting cycle) $(\mathbf{c}, \mathbf{d})$. Means followed by the same letter (s) on the bar do not differ significantly based on LSD at $p<0.05$.

Soybean seeds harvested at maturity stage R7 and R8 had significantly lower MGT (3.3 and 3.2 days, respectively), while those from $R 6, R 8+4$ and $R 8+10$ had values ranging from 3.4 to 3.6 days. On the other hand, the highest MGT (3.8 days) was recoded in P1-POL being significantly different from the other production environments, while the lowest MGT was recorded in P1-MI which was 3.1 days. There was no significant difference in CVG from R6 to R8 + 5 days and it was ranged from 29.6 to 31.0. P1-MI and P2-MI showed the highest CVGs which were 32.5 and 31.0, respectively, among all the production environments tested (Figure 3).

\subsection{Electrical Conductivity}

The loss of electrolytes from seeds to imbibition water can be detected by evaluating the electrical conductivity (EC), and indicates the intactness of the membrane. There was a significant interaction between the production environment and maturity stage for electrical conductivity of leachates. Higher EC values indicate lower seed quality as it relates to the membrane permeability. Higher EC values were recorded at maturity stage R6 irrespective of the production environments. Among the production environments, the highest EC value $\left(290.8 \mu \mathrm{S} \mathrm{cm}^{-1} \mathrm{~g}^{-1}\right)$ was recorded at maturity stage R6 in P2-ALU environment followed by same maturity stage in P1-ALU $\left(251.6 \mu \mathrm{S} \mathrm{cm}^{-1} \mathrm{~g}^{-1}\right)$ and P2-POL $\left(242.0 \mu \mathrm{S} \mathrm{cm}^{-1} \mathrm{~g}-1\right)$, all three being classified as the wet environment (Figure 4).

Meanwhile, seeds that matured in dry environment (P1-POL, P1-MI and P2-MI) recorded low EC value at R6 maturity stage compared with the seed lot which matured in the wet environment. The EC value gradually reduced with maturity until R8. There was no significant difference in EC value at R8 for P1-MI, P2-MI, P1-POL, P2-POL and P2-ALU, EC values ranged from 18.5 to $27.5 \mu \mathrm{S} \mathrm{cm}^{-1} \mathrm{~g}^{-1}$. However, comparatively high EC value $\left(48.5 \mu \mathrm{S} \mathrm{cm}^{-1} \mathrm{~g}^{-1}\right)$ was obtained at P1-ALU production environment. When synchronized with other quality parameters, increased EC values in the late maturity stages fluctuated in all production environments. 


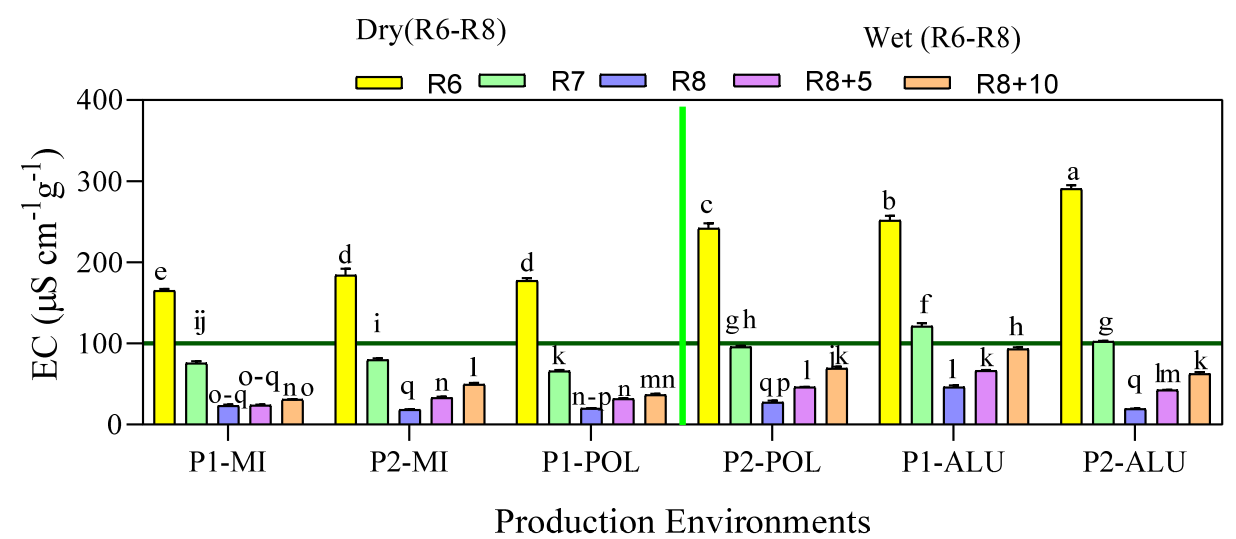

Figure 4. Electrical conductivity (EC) $\left(\mu \mathrm{Scm}^{-1} \mathrm{~g}^{-1}\right)$ as affected by the interaction between the production environment (location $\times$ planting cycle) and maturity groups. Means followed by the same letters do not differ significantly between the production environments $\times$ maturity group using Ls means at $p<0.05$. Wet and dry were grouped based on the late reproductive stage environmental condition.

\subsection{Soluble Sugar}

The most abundant soluble sugar in soybean seeds is glucose, sucrose and raffinose family oligosaccharides (RFOs). During initial seed development, glucose plays a vital role in cell division, cell development, and accumulation of storage carbohydrate, while sucrose and RFOs play a vital role in seed maturation stage by protecting cell membrane from extreme dehydration. In general, the presence of glucose in dry mature seed is negatively correlated with seed quality. On the other hand, availability of sucrose and RFOs is positively correlated in terms of seed quality. There was no significant interaction in the production environment and maturity stages on glucose content of seeds, but each of the factors individually affected the glucose content of the seeds. In contrast, significant interaction was observed between sucrose and RFOs (Figure 5).

There was no significant difference in glucose content at P1-MI, P2-MI, P1-POL, and P2POL production environments. Seeds matured in wet environments; P1-ALU and P2-ALU showed $44 \%$ higher glucose content $(>0.06 \mathrm{~g} / 100 \mathrm{~g})$, when compared with other production environments. Seed glucose content gradually decreased from maturity stages R6 to R8 before increasing at late maturity stages. There was no significant difference in sucrose content at R8 in all the production environments except for P2-POL. A notable difference was recorded in the P2-POL which recorded the highest cumulative GDD (1191) during reproductive phases (ER and LR) with the highest rainfall during LR stage $(166.6 \mathrm{~mm})$, thus heat stress conditions and hot humid condition could be the reason for less accumulation of sucrose content in the seeds (Table 1). In general, the R6 stage showed lower amount of sucrose and RFOs. There was no clear trend for sucrose and RFOs for the rest of the maturity stages at all the other production environments. 

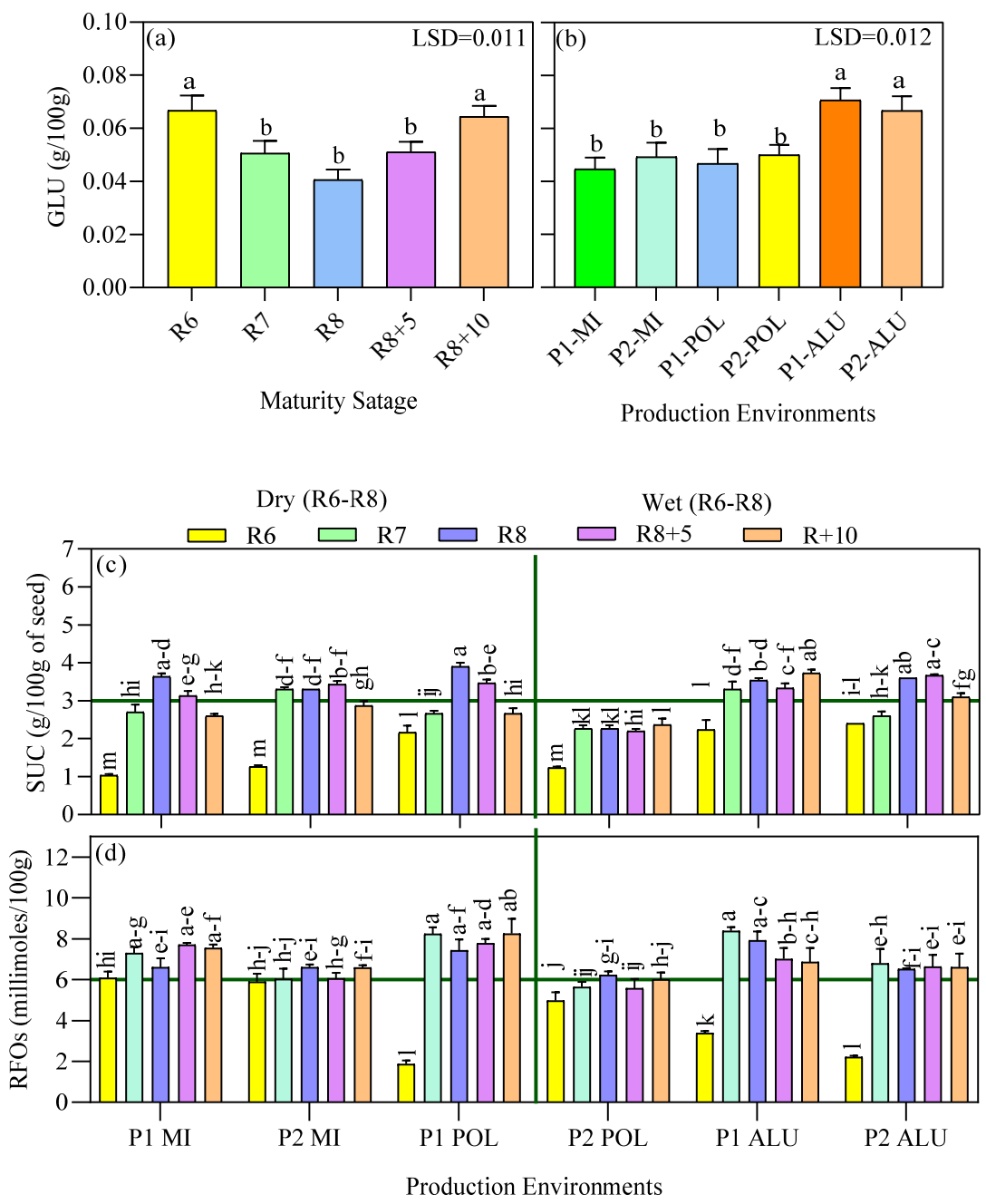

Figure 5. Glucose (GLU) content of the seed as affected by different maturity stages (a) and production environments (location $\times$ planting cycle) $(\mathbf{b})$. Means followed by the same letter on the bar do not differ significantly based on LSD at $p<0.05$. Sucrose (SUC) (c) and RFOs (d) as affected by the interaction between the production environment (location $\times$ planting cycle) and maturity stages. Means followed by the same letters do not differ significantly between the production environments $\times$ maturity stages using Ls means at $p<0.05$.

\subsection{Antioxidant Enzyme}

CAT and POD activities were significantly affected by maturity stages and production environments as shown in Figure 6.

The CAT and POD activities increased from maturity stages R6 to R8 and reduced thereafter when harvesting was delayed. Rate of reduction was affected by the production environments. The highest amount of both CAT and POD activities were recorded in R8 maturity stage irrespective of the production environments. The lowest catalase activity $(18.2 \mu \mathrm{mol} / \mathrm{min} / \mathrm{FW})$ was recorded in P1 ALU and there was no significant difference in CAT activities at the other production environments. The highest peroxidation activity $(113.0 \mathrm{nmol} / \mathrm{min} / \mathrm{mg} \mathrm{FW})$ was recorded at maturity stage R8 at P1 MI environment, followed by P1-POL, P2-MI and P2-POL, 84.4, 83.6, and $77.5 \mathrm{nmol} / \mathrm{min} / \mathrm{mg}$ FW, respectively, at the same maturity stage. Rapid reduction of antioxidant activity was observed in the late maturity stage (R8 + 10) compared with R8 at P1 ALU, P2 ALU, which were $73 \%$ and $59 \%$ (CAT) and 59\% and 49\% (POD), correspondingly. On the other hand, slower reduction rate was recorded between the same maturity stages at P1 MI and P2 MI with 5\% and 31\% (CAT) and $21 \%$ and $31 \%$ (POD), respectively (Figure 6). 


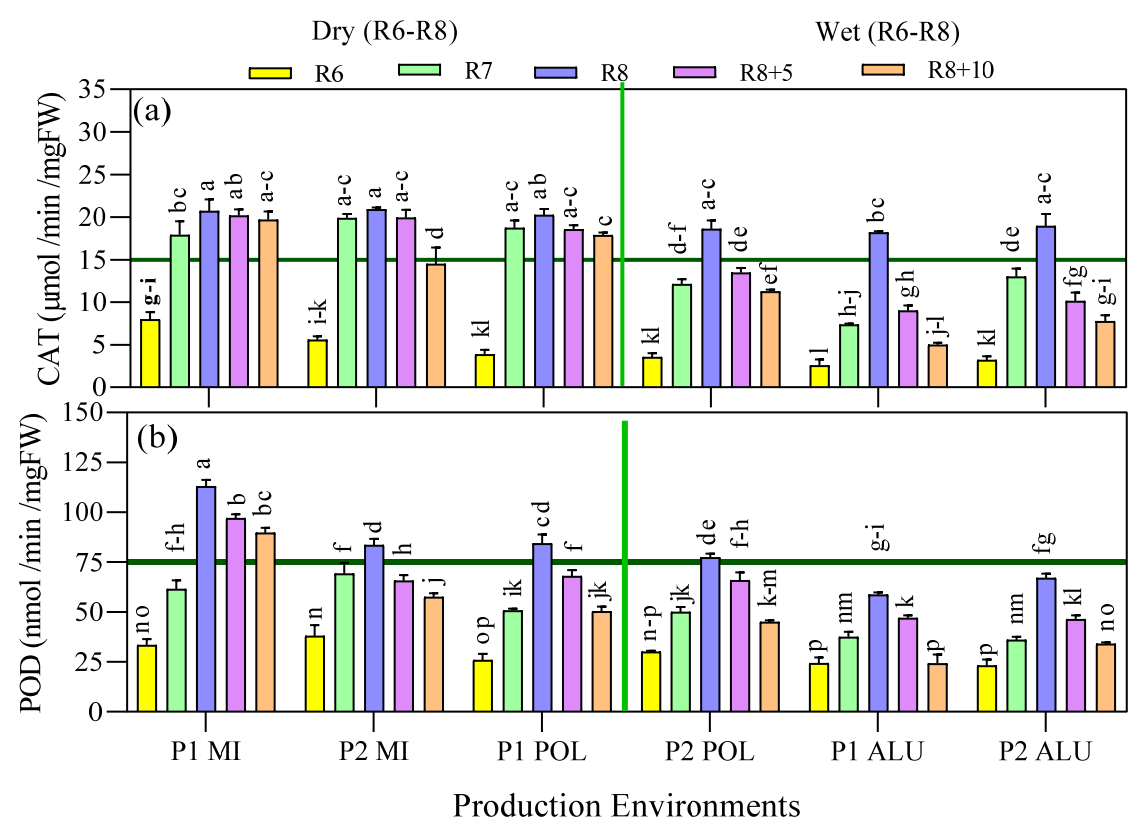

Figure 6. (a) Catalase activity (CAT) and (b) peroxidase activity (POD) as affected by the interaction between the production environment and harvesting maturity stages. Data are presented as mean \pm SE of three replicates. Means followed by the same letters do not differ significantly using Ls means at $p<0.05$. Wet and dry were grouped based on the late reproductive stage environments condition.

\subsection{Seed Yield}

This study resulted in a significant yield difference among the production environments, maturity stages and their interaction (Table 2).

Table 2. Seed yield $\pm \mathrm{SE}\left(\mathrm{g} / \mathrm{m}^{2}\right)$ at different harvesting maturity stages (R6, R7, R8, R8 +5 days and R8 + 10 days) in six production environments (P1-MI, P2-M1, P1-POL, P2-POL, P1-ALU, and P2-ALU).

\begin{tabular}{|c|c|c|c|c|c|}
\hline \multirow{3}{*}{ Production Environments } & \multicolumn{5}{|c|}{ Harvest Maturity Stages } \\
\hline & \multicolumn{5}{|c|}{ Seed Yield + SE $\left(\mathrm{g} / \mathrm{m}^{2}\right)$} \\
\hline & R6 & R7 & R8 & $\mathbf{R 8}+5$ & $\mathrm{R} 8+10$ \\
\hline P1 MI & $79.7 \pm 2.4 \mathrm{pq}$ & $224.1 \pm 7.8 \mathrm{~b}-\mathrm{d}$ & $239.2 \pm 7.7 b$ & $227.3 \pm 15.5 \mathrm{~b}-\mathrm{d}$ & $235.6 \pm 15.4 \mathrm{bc}$ \\
\hline P2 MI & $99.1 \pm 3.3$ op & $126.8 \pm 9.6 \mathrm{mn}$ & $265.1 \pm 18.4 \mathrm{a}$ & $242.1 \pm 8.5 \mathrm{ab}$ & $226.3 \pm 11.8 \mathrm{~b}-\mathrm{d}$ \\
\hline P1 POL & $110.1 \pm 4.0$ no & $177.7 \pm 5.6 \mathrm{~h}-\mathrm{k}$ & $182.6 \pm 6.6 \mathrm{~h}-\mathrm{j}$ & $184.3 \pm 6.4 \mathrm{~g}-\mathrm{j}$ & $186.9 \pm 6.5 \mathrm{f}-\mathrm{h}$ \\
\hline P2 POL & $82.8 \pm 1.8 \mathrm{pq}$ & $185.5 \pm 11.1 \mathrm{f}-\mathrm{i}$ & $207.2 \pm 12.6 \mathrm{~d}-\mathrm{g}$ & $226.8 \pm 2.3 \mathrm{~b}-\mathrm{d}$ & $215.6 \pm 1.5 c-f$ \\
\hline P1 ALU & $124.0 \pm 1.8 \mathrm{~nm}$ & $167.4 \pm 6.0 \mathrm{i}-\mathrm{k}$ & $219.0 \pm 4.9 \mathrm{~b}-\mathrm{e}$ & $156.9 \pm 4.3 \mathrm{k}-1$ & $141.6 \pm 5.5 \mathrm{~lm}$ \\
\hline P2 ALU & $58.4 \pm 1.6 \mathrm{q}$ & $162.7 \pm 6.4 \mathrm{j}-1$ & $190.0 \pm 6.3 \mathrm{f}-\mathrm{i}$ & $192.3 \pm 7.0 \mathrm{f}-\mathrm{h}$ & $195.1 \pm 11.0 \mathrm{e}-\mathrm{h}$ \\
\hline
\end{tabular}

Note: Means values marked with different small letters indicates significant difference at $p<0.05$ level.

The yield when harvested at R6, irrespective of the production environment, was low due to incomplete seed filling. There was no significant difference in seed yield among $R 8$, R8 + 5 day and R8 + 10 days maturity stages within production environments for P1-MI, P2-ALU, P1-POL and P2-POL. However, yield reduction of $14.6 \%$ and $35.3 \%$ was observed at R8 + 10 days maturity stage compared to R8 in P2-MI and P1-ALU, respectively. There was no significant difference in seed yield between R7 and R8 in P1-MI, P1-POL and P2-POL environments. The lowest yield $\left(182.6 \mathrm{gm}^{-2}\right)$ of $\mathrm{R} 8$ maturity stage was recorded in P1-POL which was the shortest total growing period (80.8 days) recorded, while the highest yield $\left(265.1 \mathrm{gm}^{-2}\right)$ was recorded for the same stage at P2-MI, which was the longest total growing period (100.4 days) recorded. 


\subsection{Seed Moisture Content at Harvest}

The moisture content of seeds at harvest varied in different harvesting maturity stages in different production environments. Figure 7 illustrates the results of moisture content for seeds harvested at different maturity stages (from R6 to R8 + 10 days).

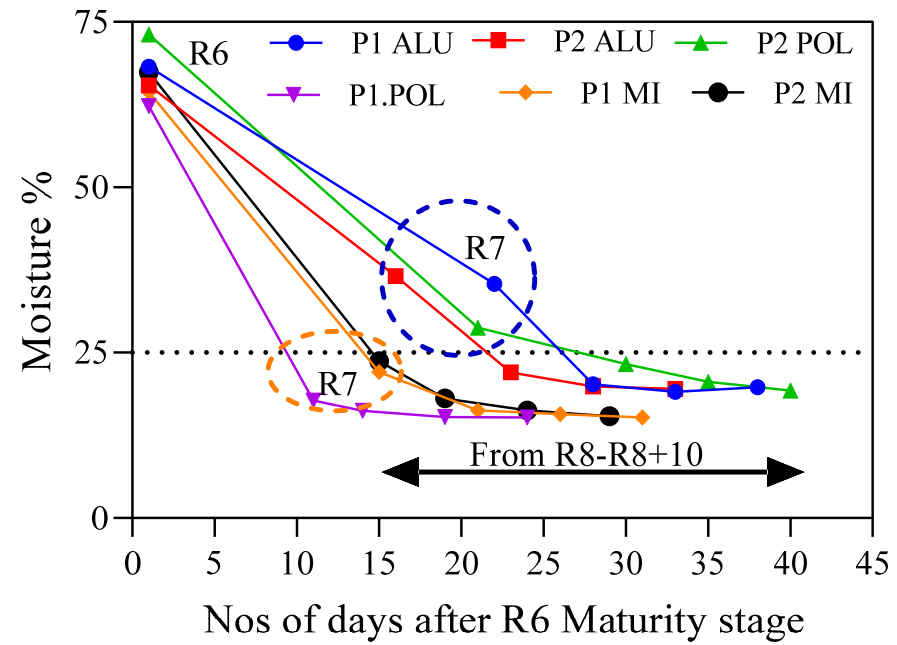

Figure 7. Moisture content of different harvesting maturity stages (R6, R7, R8, R8 + 5 and R8 + 10) at different production environments.

It was evident that, irrespective of the production environment, high moisture content was observed in R6 maturity stages, and it ranged from $62.3 \%$ to $73.1 \%$. Those seed lots that matured in dry environments (P1-M1. P2-M1 and P1-POL) recorded less than 25\% moisture content at R7 maturity stages while it was above $25 \%$ in wet environments (P2POL, P1-ALU and P2 ALU). There were no clear variations among the remaining maturity stages within wet and dry environment conditions.

\subsection{Correlations}

The correlation coefficients were significantly different among the seeds and seedling quality parameters (Table 3).

Table 3. Pearson correlations among seed and seedling quality parameters of production environments $\times$ maturity stages.

\begin{tabular}{|c|c|c|c|c|c|c|c|c|c|c|}
\hline & 1 & 2 & 3 & 4 & 5 & 6 & 7 & 8 & 9 & 10 \\
\hline (1) $\mathrm{FG} \%$ & 1.00 & & & & & & & & & \\
\hline (2) GI & $0.97^{* *}$ & 1.00 & & & & & & & & \\
\hline (3) CVG & $0.19 \mathrm{~ns}$ & $0.40^{* *}$ & 1.00 & & & & & & & \\
\hline (4) EC & $-0.85^{* *}$ & $-0.81^{* *}$ & $-0.04 \mathrm{~ns}$ & 1.00 & & & & & & \\
\hline (5) SVI & $0.95^{* *}$ & $0.93^{* *}$ & 0.21 * & $-0.81 * *$ & 1.00 & & & & & \\
\hline (6) GLU & $-0.50^{* *}$ & $-0.48 *$ & $0.02 \mathrm{~ns}$ & $0.43^{* *}$ & $-0.50^{* *}$ & 1.00 & & & & \\
\hline (7) SUC & $0.49 * *$ & $0.47^{* *}$ & $0.03 \mathrm{~ns}$ & $-0.62 * *$ & $0.50^{* *}$ & $-0.11 \mathrm{~ns}$ & 1.00 & & & \\
\hline (8) RFOs & $0.62^{* *}$ & $0.56^{* *}$ & $-0.02 \mathrm{~ns}$ & $-0.67^{* *}$ & $0.63^{* *}$ & $-0.31^{* *}$ & 0.40 ** & 1.00 & & \\
\hline (9) CAT & $0.94^{* *}$ & 0.91 ** & $0.14 \mathrm{~ns}$ & $-0.81^{* *}$ & $0.91 * *$ & $-0.53^{* *}$ & $0.48^{* *}$ & 0.56 * & 1.00 & \\
\hline (10) POD & $0.86^{* *}$ & $0.87^{* *}$ & 0.26 * & -0.72 ** & $0.89 *$ & $-0.49 * *$ & $0.41^{* *}$ & 0.43 * & 0.84 * & 1.00 \\
\hline
\end{tabular}

$*, * *$ Significant at $5 \%$ level and $1 \%$ level and ns not significant $n=90$.

Correlation analysis revealed that the final germination percentage had strong positive correlation with germination index $\left(\mathrm{r}=0.97^{* *}\right)$, seedling vigor index $\left(\mathrm{r}=0.95^{* *}\right)$, catalase $\left(\mathrm{r}=0.94^{* *}\right)$, and peroxidase $\left(0.86^{* *}\right)$. Negative correlations were observed between final germination percentage, electrical conductivity $\left(r=-0.85^{* *}\right)$, and glucose content $\left(\mathrm{r}=-0.50^{* *}\right)$. 


\section{Discussion}

\subsection{Seed Development, Maturation and Production Environment}

Soybean grown in the different environments significantly influenced the duration required for crop maturation, which varied from 80.8 to 100.4 days. Interestingly, the shortest time to maturity ( 80.8 days), and the longest time to maturity (100.8 days) were observed in the same location i.e., POL in the different planting cycles (P1 POL and P2 POL) (Figure 1). This result clearly indicates that harvesting at a fixed number of days after planting as practiced currently is not suitable. Several other studies also reported that environmental conditions of the mother plant which prevails at different growing stages, critically influence the plant growth, development, yield and seed quality $[12,15,43]$. In particular, the duration of vegetative and reproductive phases was influenced by the various factors such as temperature [11,44-46], rainfall [47], and photoperiod [48]. However, Sri Lanka being a country close to the equator, the day-length is 12 hours throughout the year. Therefore, temperature, rainfall and relative humidity are the significant deciding factors on the growth differences of soybean in a tropical country.

The findings of this study showed that SS to R1 and R1 to R6 were minimally influenced by the environmental variations which ranged from 66 to 70 days. Thus, the late reproductive stage was the only stage which contributed to the variation in the total growing period of soybean produced in the different production environment. When the late reproductive stage (LR) coincided with wet environment (P2-POL, P1-ALU, and P2-ALU), the duration was prolonged by 27.5 days, while in the dry environment (P1-MI, P2-MI and P1-POL), it required only 17.5 days (Figure 1 ). This is in accordance with the findings of Olivares et al. [47], who showed that extension of reproductive growing period in wild oat (Avena barbata) occurred due to rainy spells during their reproductive stage. During the LR stage, moisture content of the seeds gradually decreased, and the rate of moisture reduction and the equilibrium moisture content of the harvested seeds depended completely on the surrounding environmental conditions (temperature and relative humidity) [23]. Relatively slower moisture reduction rate $\left(1.8 \%\right.$ day $\left.^{-1}\right)$ at R6-R7 was observed in wet compared with the dry environments $\left(3.3 \%\right.$ day $\left.^{-1}\right)$. In dry environment, the atmosphere contains a high vapor pressure deficit while wet environment contains a low vapor pressure deficit, hence high and low moisture removal rates could be observed, respectively. As a result, 19.7 days were taken to reach R6 maturity stage to R7 in wet environments, and only 13.7 days were recorded in dry environment for the same process (Figure 7). This is the main reason for the prolonged late reproductive stage observed in the wet environmental condition.

\subsection{Seed and Seedling Quality}

According to Fehr and Caviness [25], the maturity stage where 95\% of pods turned brown in color is called R8. According to our results, different numbers of days were taken to achieve R8 maturity stage under different production environments, and different seed and seeding qualities were obtained. This finding was consistent with Castro et al. [28] and Giurizatto et al. [30], who reported R8 was the suitable maturity stage for harvesting for maximum seed quality in soybean. In contrast to harvesting at R8, a number of previous studies $[27,29]$ have also recommended maturity stage R7 as the best harvesting stage for soybean. From this study, R8 is recommended as it showed maximum quality cutting across various environmental conditions, however, for seeds that mature in dry environments (P1-MI, P2-MI and P1-POL) harvesting earlier at stage R7 resulted in seeds that comply to the minimum quality standard.

The maturation drying is the last phase of seed development, and during this time, the moisture content of seeds decreased through the process of dehydration [49]. A number of protective mechanisms have been proposed during maturation drying period including cell membrane stabilization, metabolic switch-off, accumulation of protective mechanism, removal of ROS, and trigger of enzyme synthesis to achieve successful germination leading to enhanced seed vigor $[4,7,50]$. This study clearly exhibited that the variations in environmental condition during maturation drying process result in seeds with different vigor 
levels. Accelerated maturation drying process was observed in dry environments, with seeds complying to minimum quality standards when harvested from maturity stage R7. In contrast, slow maturation drying process was observed in the wet environment, with seeds at maturity stage R7 having high moisture content (>25\%) (Figure 7). Vergara et al. [20] reported that high moisture content at the time of harvesting causes injuries to soybean seeds which leads to lower seed and seedling qualities. It is widely accepted that maximum seed quality is obtained at the stage when the supply of assimilates to the seeds were terminated, which is termed as physiological maturity [51]. After the physiological maturity, the funiculus is loosened functionally, and as a result dry matter cannot be transferred from mother plant to seed, and seeds undergo the process of deterioration. The deterioration rate depends on the prevailing weather conditions at the seed maturation periods, and the number of days the seeds remain in the late reproductive stage. The current study showed that wet weather which prevailed during the late reproduction stage increased the deterioration rate in delayed maturity stages. Similar findings were also reported for delayed harvest soybean seeds, for example, R8 + 14 days [30], at $R 8+15$ days, $R 8+30$ days [24], $R 8+20$ days [52].

Among the environmental variabilities, temperature is another key factors which affects seed development and quality. The most common temperature index which can be used to estimate the heat stress of the plant during a particular growing stage is growing degree of days (GDD), also called crop heat units [53,54]. Our findings clearly demonstrated that seed deterioration was further accelerated at P2-POL, P1-ALU, and P2-ALU due to the exposure of more than 400 GDD during the LR stage, and it was mainly due to exceeding the threshold heat limit during that particular period (Table 1). Further, it is in line with a previous study which reported that exposure to high heat and humidity during seed maturation could result in lower seed quality [55].

\subsection{Electrical Conductivity}

The current study indicated lower EC value $\left(<30.0 \mu \mathrm{S} \mathrm{cm}^{-1} \mathrm{~g}^{-1}\right)$ at R8 in all the production environments, suggesting perseverance of membrane integrity which protects the tissues from the oxidative damage. Thus, this could also explain the higher germinability of seeds harvested at R8. In contrast, higher EC values particularly in the late maturity stages (R8 +5 days and R8 +10 days) for seed produced at P2-POL, P1-ALU and P2-ALU could be due to rapid loss of membrane integrity because of prolonged exposure of hot ( $>400 \mathrm{GDD}$ ) and wet $(>75 \% \mathrm{RH}$ or $>100 \mathrm{~mm} \mathrm{RF}$ ) conditions. Our findings were in line with Forti et al. [56] who reported that damage to tissues due to weather can occur as a consequence of oxidative damage during the heat stress after physiological maturity. However, there was no significant difference between EC values and seed quality traits (FG\%, GI, GRI, and SVI) in R8 and late maturity stages of R8 + 5 days and R8 + 10 days in P1-MI, where seeds were exposed to low heat stress (388 GDD) and dry conditions during the LR stage (Figures 2 and 4). Thus, the results confirmed that oxidative stress was minimized at the LR stage under dry conditions.

\subsection{Soluble Sugar}

Soluble sugars are a significant seed constituent and deposited in the primary storage tissues of seed during development [57] in different quantities [58]. The amount of soluble sugar deposition is fundamentally determined by genetic factors, maturity stages and production environments. Our study revealed positive correlations between FG\% and sucrose and RFOs content and a negative correlation was found between FG\% and the glucose content of the dry seeds. Various studies reported that high amount of reducing sugar (glucose) in dry seeds weakens protein constituents, resulting in low seed and seedling quality. The formation of reducing sugar in hot and wet environments was due to the triggered action of hydrolytic enzymes which were hydrolyzed complex sugars to glucose. It could be the reason for low performance of seed and seedling quality of P1-ALU and P2-ALU, which showed higher glucose content in dry seeds (Figure 5). Furthermore, 
the present study was found to have moderate negative correlations between sucrose and RFOs with EC values of $\left(\mathrm{r}=-0.62^{* *}\right)$ and $\left(\mathrm{r}=-0.67^{* *}\right)$, respectively. This result is consistent with several studies [54-56] that reported sucrose and RFOs might be involved in membrane stabilization.

\subsection{Antioxidant Enzyme}

The strength of the antioxidant enzymatic defense mechanism plays a vital role in seed and seedling quality traits since it leads to scavenging ROS produced by various abiotic and biotic stress conditions. Therefore, insufficient concentration of antioxidants to scavenge the ROS could lead to seed deterioration process. Our findings clearly confirmed that at late maturity stages (R8 +5 days and R $8+10$ days) loss of antioxidant (CAT and POD) activity occurred leading to rapid reduction of germination trait (FG\%, GI, GRI and SVI) under wet environment (P2-POL, P1-ALU and P2-ALU) (Figures 2 and 6). It was further confirmed by the correlation analysis results which revealed strong positive correlations between antioxidant enzyme activities (CAT and POD) and seed and seedling qualities (FG\%, GI and SVI) (Table 2). This finding is consistent with [59], who suggested that physiological quality reduction only appeared with the inactivation of a range of antioxidant enzymes responsible for ROS scavenging.

\subsection{Seed Yield}

The number of plants per unit area, number of pods per plant, seed number per pod, and average seed weight are the soybean yield components, and these yield components depend on environmental conditions [15]. Carmello et al. [60] reported that rainfall and temperature are the primary factors responsible for the grain yield fluctuation in much of the tropics. The present study showed that environments that experienced wet condition with temperature below the maximum tolerance level $\left(<33^{\circ} \mathrm{C}\right)$ during ER stage (Table 1$)$, such as P1-M1, P2-MI, and P1-ALU, showed higher yield compared to the average of six environments. The availability of adequate water content and the absence of heat stress during seed filling stage in these environments could be the reason for higher yield. In contrast, the other three environments which coincide with $\geq 35^{\circ} \mathrm{C}$ and dry condition during the early reproductive stages (Table 1 ) had lower seed yield. Our findings were consistent with several previous studies which reported that the increment of temperature even for a short period of exposure (only three days) above the maximum tolerance level negatively affected soybean yield component and yield [44]. However, the six environments tested in this study, maintained seed yield above the minimum yield level $\left(>150 \mathrm{gm}^{-2}\right)$ designated for the PB-1 variety. The current finding provides the much-needed encouragement for the government to expand the seed production area in Sri Lanka, with ensured seed quality standards.

\subsection{Programming of Seed Production Activities}

This study acts as a guideline for the selection of suitable production environments in Sri Lanka to produce good quality soybean seeds as planting material. Since the amount of rainfall, relative humidity, and temperature were the critical factors that influenced the seed quality, our result showed that more than $100 \mathrm{~mm}$ of rainfall during late reproductive stage negatively affected soybean seed and seedling quality, it is suggested that long term rainfall data analysis would be advantageous when designing the seed production process to obtain the above-mentioned minimum quality standards. Based on that, May to August season is suggested for the first round of planting, while the season from January to March would be ideal for the second round of planting (Figure 8). 

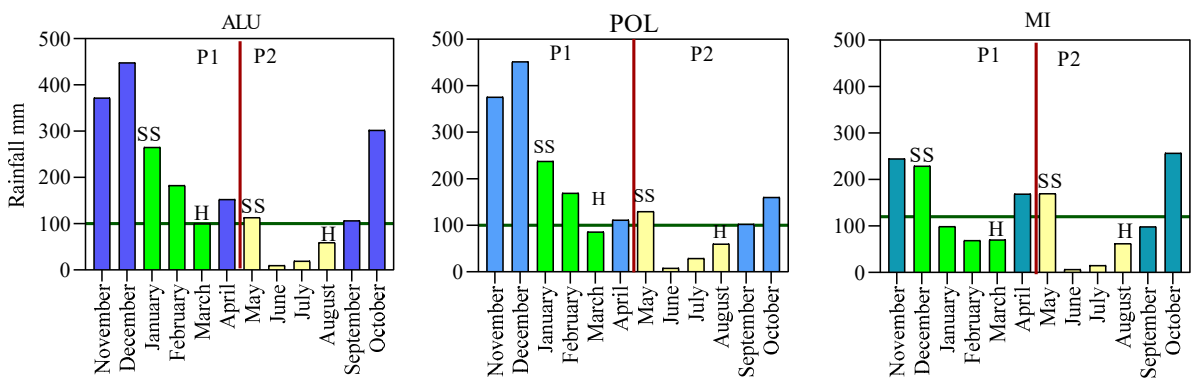

Figure 8. Long term (2009-2019) mean cumulative monthly rainfall (mm) of three production location Aluttarama (ALU), Polonnaruwa (POL) and Mahailluppalama (MI). Source: Natural resource management division, Department of Agriculture Sri Lanka.

\section{Conclusions}

This study identified the significant effect of both the production environment and harvest maturity stage on initial seed and seedling quality as well as final seed mass. Maternal environmental conditions at the late reproductive stage (R6-R8) are the most critical factor in determining the initial seed quality. Rapid seed deterioration in the field occurred when more than $100 \mathrm{~mm}$ of cumulative rainfall coincided with the late reproductive stage. In a dry environment, both R7 and R8 maturity stages can produce seed lots having above minimum quality standard ( $75 \%$ of final germination, germination index of 300 , germination rate index of $25 \%$ per day and seedling vigor index of 2500 ); however, in the wet environment only maturity stage $\mathrm{R} 8$ surpassed the minimum level. Therefore, the R8 maturity stage is recommended irrespective of the production environment for soybean variety $\mathrm{PB}-1$, with variation in time taken to attain this stage. In dry environment maturity stage $\mathrm{R} 8$ can be attained within 80 days while in wet environment it can exceed 100 days. The current seed production area (MI) can be expanded to POL (P1 and P2) and ALU (P2) by managing planting time (P1 January and P2 June) to coincide with less than $100 \mathrm{~mm}$ of cumulative rainfall during the late reproductive stage (R6-R8). It is expected that with expansion based on above recommendations, the country can benefit from a 2.5 -fold increase in seed production.

Author Contributions: Conceptualization, I.W., U.R.S.; methodology, I.W.; formal analysis, I.W., S.A.A. and M.N.G.; investigation, I.W.; data curation, I.W. and U.R.S.; writing-original draft preparation, I.W.; writing—review and editing, I.W., S.A.A. and M.N.G.; visualization, I.W. and U.R.S.; supervision, U.R.S., P.N. and M.H.N.; project administration, I.W. and U.R.S.; funding acquisition, U.R.S. All authors have read and agreed to the published version of the manuscript.

Funding: This research received no external funding.

Institutional Review Board Statement: Not Applicable.

Informed Consent Statement: Not Applicable.

Data Availability Statement: The data presented in this study are available on request from the corrosponding author. The data are not publicly available.

Acknowledgments: The authors acknowledge the assistance of the Sri Lanka Council for the Agricultural Research Policy (SLCARP), Department of Agriculture, Sri Lanka for facilitating to conduct this research, the staff of seed and planting material development center and seed certification service of Department of Agriculture, Sri Lanka who facilitated the field study and seed quality analysis, laboratory staff of the Department of Crop Science, Faculty of Agriculture, Universiti Putra Malaysia who facilitated the use of instruments for seed quality analysis.

Conflicts of Interest: The authors declare no conflict of interest. 


\section{References}

1. Nguyen, H.T.; Bhattacharyya, M.K. The Soybean Genome; Springer: Columbia, CO, USA, 2017. [CrossRef]

2. Ministry of Agriculture. Presidential Task Force on National Food Production. In Food Production Book; Ministry of Agriculture: Battaramulla, Sri Lanka, 2015.

3. Aberathne, M.S.; Chithrapala, N.H.M.S. Present Status, Constrains and Strategies to Increase Soybean Production in Sri Lanka. In Annals of Sri Lanka Department of Agriculture; Department of Agriculture: Battaramulla, Sri Lanka, 2013; pp. $193-206$.

4. Angelovici, R.; Galili, G.; Fernie, A.R.; Fait, A. Seed Desiccation: A Bridge between Maturation and Germination. Trends Plant Sci. 2010, 15, 211-218. [CrossRef]

5. Hampton, J.G.; Boelt, B.; Rolston, M.P.; Chastain, T.G. Effects of Elevated $\mathrm{CO}_{2}$ and Temperature on Seed Quality. J. Agric. Sci. 2013, 151, 154-162. [CrossRef]

6. Li, R.; Chen, L.; Wu, Y.; Zhang, R.; Baskin, C.C.; Baskin, J.M.; Hu, X. Effects of Cultivar and Maternal Environment on Seed Quality in Vicia Sativa. Front. Plant Sci. 2017, 8, 1-9. [CrossRef]

7. Bareke, T. Biology of Seed Development and Germination Physiology. Adv. Plant Agric. Res. 2018, 8, 336-346. [CrossRef]

8. Szczerba, A.; Pła, A.; Pastuszak, J.; Kope, P. Effect of Low Temperature on Germination, Growth, and Seed Yield of Four Soybean (Glycine max L.) Cultivars. Agronomy 2021, 11, 800. [CrossRef]

9. Štraus, S.; Hladnik, A.; Ceh, B. Impact of Linseed Variety, Location and Production Year on Seed Yield, Oil Content and Its Composition. Agronomy 2020, 10, 1-13.

10. Sobko, O.; Stahl, A.; Hahn, V.; Zikeli, S.; Claupein, W.; Gruber, S. Environmental Effects on Soybean (Glycine max (L.) Merr) Production in Central and South Germany. Agronomy 2020, 10, 847. [CrossRef]

11. Liu, X.; Jin, J.; Wang, G.; Herbert, S.J. Soybean Yield Physiology and Development of High-Yielding Practices in Northeast China. Field Crop Res. 2008, 105, 157-171. [CrossRef]

12. Kuswantoro, H. Effect of Planting Dates on Growth, Yield, and Phenology of Different Soybean Lines Grown under Tidal Swamp Land. Pertanika J. Trop. Agric. Sci. 2018, 41, 1261-1274.

13. Copeland, L.O.; McDonald, M.B. Principles of Seed Science and Technology; Kluwer Academic Publishers: London, UK, 2001. [CrossRef]

14. De Pádua, G.P.; de França-neto, J.B.; Carvalho, M.; de Laene, M.; Krzyzanowski, F.C.; GuiMarães, R.M. Incidnce of Green Soybean Seeds as a Function of Environmenral Stresses during Seed Maturation. Rev. Bras. Sementes 2009, 31, 150-159. [CrossRef]

15. Bakal, H.; Gulluoglu, L.; Onat, B.; Arioglu, H. The Effect of Growing Seasons on Some Agronomic and Quality Characteristics of Soybean Varieties in Mediterranean Region in Turkey. Turk. J. Field Crop. 2017, 22, 187-196. [CrossRef]

16. Wijewardana, C.; Reddy, K.R.; Bellaloui, N. Soybean Seed Physiology, Quality, and Chemical Composition under Soil Moisture Stress. Food Chem. 2019, 278, 92-100. [CrossRef]

17. Alsajri, F.A.; Wijewardana, C.; Irby, J.T.; Bellaloui, N.; Krutz, L.J.; Golden, B.; Gao, W.; Reddy, K.R. Developing Functional Relationships between Temperature and Soybean Yield and Seed Quality. Agron. J. 2020, 112, 194-204. [CrossRef]

18. Wang, L.; Patrick, J.W.; Ruan, Y.L. Live Long and Prosper: Roles of Sugar and Sugar Polymers in Seed Vigor. Mol. Plant 2018, 11, 1-3. [CrossRef]

19. Tsukahara, R.Y.; de Fonseca, I.C.B.; de Silva, M.A.E.; Kochinski, E.G.; Neto, J.P.; Suyama, J.T. Produtividade de Soja Em Consequência Do Atraso Da Colheita e de Condições Ambientais. Pesqui. Agropecu. Bras. 2016, 51, 905-915. [CrossRef]

20. Vergara, R.; da Silva, R.N.O.; Nadal, A.P.; Gadotti, G.I.; Aumonde, T.Z.; Villela, F.A. Harvest Delay, Storage and Physiological Quality of Soybean Seeds. J. Seed Sci. 2019, 41, 506-513. [CrossRef]

21. Govindaraj, M.; Masilamani, P.; Albert, V.A.; Bhaskaran, M. Role of Antioxidant in Seed Quality-A Review. Agric. Rev. 2017, 38, 180-190. [CrossRef]

22. Hasanuzzaman, M.; Bhuyan, M.H.M.B.; Zulfiqar, F.; Raza, A.; Mohsin, S.M.; Al Mahmud, J.; Fujita, M.; Fotopoulos, V. Reactive Oxygen Species and Antioxidant Defense in Plants under Abiotic Stress: Revisiting the Crucial Role of a Universal Defense Regulator. Antioxidants 2020, 9, 681. [CrossRef]

23. Martinez-Feria, R.A.; Licht, M.A.; Ordóñez, R.A.; Ha, J.L.; Coulter, J.A.; Archontoulis, S.V. Evaluating Maize and Soybean Grain Dry-down in the Field with Predictive Algorithms and Genotype-by-Environment Analysis. Sci. Rep. 2019, 9, 7167. [CrossRef] [PubMed]

24. Diniz, F.O.; Reis, M.S.; dos Dias, L.A.S.; Araújo, E.F.; Sediyama, T.; Sediyama, C.A. Qualidade Fsiológica de Sementes de Cultivares de Soja Submetidas Ao Retardamento de Colheita e Sua Relação Com a Emergência das Plântulas Em Campo. J. Seed Sci. 2013, 35, 147-152. [CrossRef]

25. Fehr, W.R.; Caviness, C.E. Stage of Development Descriptions for Soybeans, Glycine max (L.) Merrill 1. Crop Sci. 1977, 11, 929-931. [CrossRef]

26. Khan, A.Z.; Khan, H.; Khan, R.; Ghoneim, A.; Ebid, A. Seed Development Profile Soybean as Influenced by Planting Date and Cultivar under Temperate Environment. Am. J. Plant Physiol. 2007, 2, 251-260. [CrossRef]

27. Isaac, O.T.; Banful, B.K.; Amoah, S.; Apuri, S.; Seweh, E.A. Effect of Harvesting Stages on Seed Quality Characteristics of Three Soybean (Glycine max (L) Varieties). J. Sci. Eng. Res. 2016, 3, 326-333.

28. De Castro, E.M.; Oliveira, J.A.; de Lima, A.E.; dos Santos, H.O.; Barbosa, J.I.L. Physiological Quality of Soybean Seeds Produced under Artificial Rain in the Pre-Harvesting Period. J. Seed Sci. 2016, 38, 14-21. [CrossRef] 
29. Nichal, S.S.; Shinde, S.M.; Patel, W.Y.M.; Mahalle, A.R.; Nandanwar, R.S. Crop Physiological Maturity: A Proper Stage to Harvest Soybean Crop. Int. J. Curr. Microbiol. Appl. Sci. 2018, 6, 2430-2435.

30. Giurizatto, M.I.K.; de Souza, L.C.F.; Robaina, A.D.; Gonçalves, M.C. Effects of Harvest Epoch and Seed Coat Thickness on Viability and Vigor of Soybean Seeds. Agrotec Sci. 2003, 27, 771-779.

31. Minuzzi, A.; de Braccini, A.L.E.; Rangel, M.A.S.; Scapim, C.A.; Barbosa, M.C.; Paiolaalbrecht, L. Seed Quality of Four Soybean Cultivars, Harvested in Two Locations of Mato Grosso Do Sul State. Rev. Bras. Sementes 2010, 32, 176-185. [CrossRef]

32. Department of Agriculture Sri Lanka. Soybean Cultivation Guide. Available online: http://www.doa.gov.lk/FCRDI/index.php/ en/crop/101-soybean.new (accessed on 27 April 2021).

33. Egli, D.B. Cultivar Maturity and Response of Soybean to Shade Stress during Seed Filling. Field Crop. Res. 1997, 52, 1-8. [CrossRef]

34. Kumar, A.; Pandey, V.; Shekh, A.M.; Kumar, M. Growth and Yield Response of Soybean (Glycine max L.) in Relation to Temperature, Photoperiod and Sunshine Duration at Anand, Gujarat, India. Am. Eurasian J. Agron. 2008, 1, 45-50.

35. ISTA. International Rules for Seed Testing 2016; The International Seed Testing Association: Bassersdorf, Switzerland, 2016.

36. Kader, M.A.; Jutzi, S.C. Effects of Thermal and Salt Treatments during Imbibition on Germination and Seedling Growth of Sorghum at $42 / 19^{\circ} \mathrm{C}$. J. Agron. Crop Sci. 2004, 190, 35-38. [CrossRef]

37. Al-Ansari, F.; Ksiksi, T. A Quantitative Assessment of Germination Parameters: The Case of Anand. Open Ecol. J. 2016, 9, 13-21. [CrossRef]

38. Abdul-Baki, A.A.; Anderson, J.D. Vigor Determination in Soybean Seed by Multiple Criteria. Crop Sci. 1973, 13, 630. [CrossRef]

39. Dutra, A.S.; Vieira, R.D. Electrical Conductivity as Vigor Test for Squash Seeds. Braz. J. Seeds 2006, 28, 117-122.

40. Raman, M.; Saiprasad, G.V.S.; Madhavakrishna, K. From Seed to Feed: Assessment and Alleviation of Raffinose Family Oligosaccharides (RFOs) of Seed- and Sprout-Flours of Soybean [Glycine Max (L.) Merr.]—A Commercial Aspect. Int. Food Res. J. 2019, 26, 105-116.

41. Aebi, H. Catalase in Vitro. Methods Enzymol. 1984, 105, 121-126. [PubMed]

42. Maehly, C. Plant Peroxidases. Methods Enzymol. 1955, 2, 801-813.

43. Demir, I.; Ashov, A.M.; Mavi, K. Effect of Seed Production Environmnet and Time of Harvest on Tomato (Lycopersicon Esculentum) Seedling Growth. Res. J. Seed Sci. 2008, 1, 1-10.

44. Choi, D.H.; Ban, H.Y.; Seo, B.S.; Lee, K.J.; Lee, B.W. Phenology and Seed Yield Performance of Determinate Soybean Cultivars Grown at Elevated Temperatures in $\alpha$ Temperate Region. PLoS ONE 2016, 11, 165977. [CrossRef] [PubMed]

45. Zheng, H.; Chen, L.; Han, X. Response of Soybean Yield to Daytime Temperature Change during Seed Filling: A Long-Term Field Study in Northeast China. Plant Prod. Sci. 2009, 12, 526-532. [CrossRef]

46. George, T.; Bartholomew, D.; Singleton, P. Effect of Temperature and Maturity Group on Phenology of Field Grown Nodulating and Nonnodulating Soybean Isolines. Biotronics Rep. 1990, 19, 49-59.

47. Olivares, A.; Johnston, M.; Calderón, C. Effect of Rainfall Regimes on Seed Production and Quality of Avena Barbata. Cienc. Investig. Agrar. 2009, 36, 69-76. [CrossRef]

48. Hu, M.; Wiatrak, P. Effect of Planting Date on Soybean Growth, Yield, and Grain Quality: Review. Agron. J. 2012, 104, 785-790. [CrossRef]

49. Jing, Y.; Lang, S.; Wang, D.; Xue, H.; Wang, X.F. Functional Characterization of Galactinol Synthase and Raffinose Synthase in Desiccation Tolerance Acquisition in Developing Arabidopsis Seeds. J. Plant Physiol. 2018, 230, 109-121. [CrossRef] [PubMed]

50. Buitink, J.; Leprince, O. Intracellular Glasses and Seed Survival in the Dry State. Comptes Rendus Biol. 2008, 331, 788-795. [CrossRef] [PubMed]

51. Ellis, R.H. Temporal Patterns of Seed Quality Development, Decline, and Timing of Maximum Quality during Seed Development and Maturation. Seed Sci. Res. 2019, 29, 135-142. [CrossRef]

52. Gris, C.F.; von de Pinho, E.V.R.; Andrade, T.; Baldoni, A.; de Carvalho, M.L.M. Physiological Quality and Lignin Content in the Coat Seeds of Conventional and RR Transgenic Soybean Submitted to Different Harvest Periods. Cienc. Agrotecnologia 2010, 34, 374-381. [CrossRef]

53. Kaleem, S.; Fayyaz-ul-Hassan Ahmad, M.; Mahmood, I.; Wasaya, A.; Randhawa, M.A.; Khaliq, P. Effect of Growing Degree Days on Autumn Planted Sunflower. Afr. J. Biotechnol. 2011, 10, 8840-8846.

54. Parthasarathi, T.G.; Velu, P.J. Impact of Crop Heat Units on Growth and Developmental Physiology of Future Crop Production: A Review. Res. Rev. J. Crop Sci. Technol. 2013, 2, 11-18.

55. Nakagawa, A.C.S.; Ario, N.; Tomita, Y.; Tanaka, S.; Murayama, N.; Mizuta, C.; Iwaya-Inoue, M.; Ishibashi, Y. High Temperature during Soybean Seed Development Differentially Alters Lipid and Protein Metabolism. Plant Prod. Sci. 2020, $23,504-512$. [CrossRef]

56. Forti, V.A.; Carvalho, C.; Tanaka, F.A.O.; Cicero, S.M. Weathering Damage in Soybean Seeds: Assessment, Seed Anatomy and Seed Physiological Potential. Seed Technol. 2013, 35, 213-224.

57. Hu, D.; Ma, G.; Wang, Q.; Yao, J.; Wang, Y.; Pritchard, H.W.; Wang, X. Spatial and Temporal Nature of Reactive Oxygen Species Production and Programd Cell Death in Elm (Ulmus Pumila L.) Seeds during Controlled Deterioration. Plant Cell Environ. 2012, 35, 2045-2059. [CrossRef] [PubMed]

58. Lehner, A.; Bailly, C.; Flechel, B.; Poels, P.; Côme, D.; Corbineau, F. Changes in Wheat Seed Germination Ability, Soluble Carbohydrate and Antioxidant Enzyme Activities in the Embryo during the Desiccation Phase of Maturation. J. Cereal Sci. 2006, 43, 175-182. [CrossRef] 
59. Ali, I.; Nulit, R.; Ibrahim, M.H.; Uddin, M.K. Deterioration of Quality Soybean Seeds (Glycine max (L.) Merr. AGS 190) at Harvest Stages, Seed Moisture Content and Storage Temperature in Malaysia. Int. J. Biosci. 2017, 10, 372-381.

60. Carmello, V.; Santa, L.; Neto, A. Rainfall Variability and Soybean Yield in Paraná State, Southern Brazil Rainfall Variability and Soybean Yield in Paraná State, Southern. Int. J. Environ. Agric. Res. 2016, 2, 86-97. 